\title{
Peripapillary atrophy in elderly Chinese in rural and urban Beijing
}

Y Wang ${ }^{1}, \mathrm{~L} \mathrm{Xu^{1 } , \mathrm { L } \text { Zhang }}{ }^{1}, \mathrm{H}$ Yang ${ }^{1}, \mathrm{Y} M \mathrm{a}^{1}$ and JB Jonas ${ }^{2}$

\begin{abstract}
Purpose To determine peripapillary atrophy in elderly Chinese in an urban and rural regions of Beijing.

Methods The Beijing Eye Study a population-based, cross-sectional cohort study, included 4439 subjects out of 5324 subjects who were asked to participate (response rate $83.4 \%$ ). Mean age was $56.2 \pm 10.6$ years (range, 40-101 years). Colour optic disc photographs $\left(30^{\circ}\right)$ were morphometrically examined. Peripapillary atrophy was divided into alpha zone and beta zone.
\end{abstract}

Results Optic disc photographs were available for 4027 (90.7\%) subjects. Alpha zone and beta zone, respectively, were present in $2867(71.2 \%)$ subjects and $802(19.9 \%)$ subjects, respectively, measuring $0.52 \pm 0.64 \mathrm{~mm}^{2}$ and measuring $0.46 \pm 1.82 \mathrm{~mm}^{2}$. Both zones were significantly widest and found significantly $(P<0.001)$ most often in the temporal peripapillary region, followed by the temporal inferior region, the temporal superior region, and finally the nasal region. Size of both zones was significantly correlated with optic disc size $(P<0.001)$, age $(P<0.001)$, and myopic refractive error $(P<0.001)$. Both zones increased significantly with decreasing uncorrected visual acuity $(P<0.001)$ and decreasing best-corrected visual acuity $(P<0.001)$. They did not vary significantly $(P=0.10$; and $P=0.78)$ between male and female subjects. In multivariate analysis, the relationships between both zones and age, myopic refractive error, disc size, and uncorrected and best-corrected visual acuity remained statistically significant $(P<0.001)$.

Conclusions Alpha zone and beta zone of peripapillary atrophy, respectively, occur in about 70 and $20 \%$, respectively, of elderly Chinese. As peripapillary atrophy changes in glaucomatous optic neuropathy, these normative data may be helpful for glaucoma detection.

Eye (2008) 22, 261-266; doi:10.1038/sj.eye.6702601; published online 22 September 2006

Keywords: peripapillary atrophy; optic disc; neuroretinal rim; visual impairment; myopia; hyperopia

\section{Introduction}

The morphological diagnosis of the optic nerve diseases is focused on the retinal nerve fibre layer and the optic nerve head. In the latter, changes can be detected inside of the optic disc, such as loss of neuroretinal rim and deepening of the optic cup, and outside of the optic disc such as development or enlargement of peripapillary atrophy. ${ }^{1}$ Hospital-based studies and the population-based Rotterdam Study have previously examined frequency, size, and regional distribution of peripapillary atrophy in Caucasians. ${ }^{2-6}$ As data on size and frequency of peripapillary atrophy and its associations with other ocular and general parameters in Chinese have mostly not been assessed yet, the present investigation was conducted to examine peripapillary atrophy in elderly Chinese in a population-based design.

\section{Methods}

The Beijing Eye Study, a population-based cohort study in Northern China, was carried out in seven communities, four communities from the urban district Haidian in the Northern part of Central Beijing, and three communities from a rural district in the village area of Yufa (Daxing District) in the South of Beijing. The eligibility criteria for the study was an age of 40 or more years. The Medical Ethics Committee of the Beijing Tongren Hospital had approved the study protocol and all participants had given
${ }^{1}$ Department of

Ophthalmology and Eye Hospital, Tongren Hospital, Beijing, China

\section{${ }^{2}$ Department of Ophthalmology, Faculty of Clinical Medicine Mannheim, University of Heidelberg, Mannheim, Germany}

Correspondence: Professor $\mathrm{L} \mathrm{Xu}$ or Prof JB Jonas, Beijing Institute of Ophthalmology, 17 Hougou Street, Chong Wen Men, 100005 Beijing,

China

Tel: + 49621383 2652;

Fax: + 496213833803 .

E-mail: Jost.Jonas@ augen.ma.uni-heidelberg.de

Received: 11 May 2006 Accepted in revised form: 8 August 2006 Published online: 22 September 2006

Proprietary interest: none 
informed consent, according to the Declaration of Helsinki principles. The study design has been described in detail recently. ${ }^{7}$

At the time of the survey in the year 2001, there were 5324 individuals aged 40 years or older residing in those seven communities. In total, 4439 individuals (8878 eyes; 2505 women) participated in the eye examination, corresponding to an overall response rate of $83.4 \%$. From the 4439 individuals, readable optic disc photographs were available for $4027(90.7 \%)$ subjects. The rural part of the study included 1735 (43.1\%) subjects (1001 women); and the urban part 2292 (56.9\%) subjects (1265 women). Mean age (whole study population: $55.2 \pm 10.0$ years (median, 55 years; range, 40-101 years)) was significantly $(P<0.001 ; 95 \%$ confidence interval $(\mathrm{CI}):-6.55,-5.36)$ higher in the urban region $(57.8 \pm 10.0$ years) than in the rural region (51.8 \pm 9.0 years). Mean refractive error (whole study population: $-0.33 \pm 2.07$ dioptres (D) (median, 0 dioptres; range, $-18.75 \mathrm{~d}$ to +7.50 dioptres) was significantly $(P<0.001 ; 95 \% \mathrm{CI}: 0.29,0.55)$ more myopic in the urban region $(-0.51 \pm 2.21$ dioptres $)$ than in the rural area $(-0.09 \pm 1.90$ dioptres $)$. The proportion of women to men in the two study populations did not vary significantly $(P=0.12$; odds ratio: $0.90 ; 95 \%$ CI: $0.80,1.02$ ).

All examinations were carried out in the communities, either in schoolhouses or in community houses as described in detail previously. ${ }^{7}$ Photographs of the macula and optic disc were taken using a fundus camera (Type CR6-45NM, Canon Inc., USA). The optic disc was defined as all the area inside of the peripapillary scleral ring. Peripapillary chorioretinal atrophy was divided into a peripheral alpha zone and a central beta zone at the optic disc border. ${ }^{4-6}$ Alpha zone was characterized by an irregular hypopigmentation and hyperpigmentation and intimated thinning of the chorioretinal tissue layer. On its outer side it was adjacent to the retina, and on its inner side it was in touch with a zone characterized by visible sclera and visible large choroidal vessels (beta zone), or with the peripapillary scleral ring, respectively. Features of the inner zone (beta zone) were marked atrophy of the retinal pigment epithelium and of the choriocapillaris, good visibility of the large choroidal vessels and the sclera, thinning of the chorioretinal tissues, and round bounds to the adjacent alpha zone on its peripheral side and to the peripapillary scleral ring on its central side. If both zones were present, beta zone was always closer to the optic disc than alpha zone. ${ }^{4-6}$

The digitized optic disc photographs were measured by outlining the optic disc border on the computer screen and using a planimetric software program. The measurements were performed by a single examiner (YW) after a training period in which optic disc photographs of about 900 subjects had been examined and discussed together with two glaucoma specialists (LX, JBJ). The magnification by the optic media of the eye were corrected according to Littmann's method taking into account the refractive error. The anterior corneal curvature radius was set at $7.8 \mathrm{~mm} .{ }^{8}$ To check the correction of the magnification of the optic disc photographs including the magnification by the fundus camera, the optic discs of 52 eyes were additionally imaged using a confocal laser scanning tomograph (Heidelberg Retina Tomograph HRT; Heidelberg Engineering, Dossenheim, Germany). Measurements obtained by both techniques were compared with each other.

Statistical analysis was performed by using a commercially available statistical software package (SPSS for Windows, version 11.5, SPSS, Chicago, IL, USA). Only one eye per subject was taken for statistical analysis unless indicated otherwise. The data are given as mean $\pm S D$. The statistical strength of correlations were reported as correlation coefficient $r$ or $r^{2}$. Odds ratios and 95\% CIs were presented. All $P$-values were two-sided and were considered statistically significant when the values were less than 0.05 .

\section{Results}

Alpha zone was found in $2867(71.2 \%)$ subjects. It occurred significantly $(P<0.001)$ more often in the temporal peripapillary region $(2836 / 4027$ or $70.4 \%)$ than in the temporal inferior region $(1298 / 4027$ or $32.2 \%)$, in which was detected significantly $(P<0.001)$ more often than in the temporal superior region $(1138 / 4027$ or $28.3 \%)$. In both latter regions, it was seen significantly $(P<0.001)$ more often than in the nasal region $(234 / 4027$ or $5.8 \%)$.

Mean area of alpha zone measured $0.52 \pm 0.64 \mathrm{~mm}^{2}$ (median, $0.44 \mathrm{~mm}^{2}$; range $0.00-13.72 \mathrm{~mm}^{2}$ ). Alpha zone was significantly wider in the temporal peripapillary region than in the temporal inferior region and the temporal superior region. In both latter regions, it was significantly wider than in the nasal region.

Alpha zone was significantly correlated with optic disc size (correlation coefficient $r=0.12 ; P<0.001 ; 95 \% \mathrm{CI}$ : $0.095,0.165)$. It increased significantly $(P<0.001 ; r=0.12$; 95\% CI: 0.005, 0.009) with age (Figure 1; Equation of the regression line: Area Alpha Zone $\left(\mathrm{mm}^{2}\right)$ :

$0.007 \times$ Refractive Error (dioptres) +0.12$)$ and myopic refractive error $(r=-0.11 ; P<0.001)$ (Figure 2; Equation of the regression line: Area Alpha Zone $\left(\mathrm{mm}^{2}\right)$ :

$-0.03 \times$ Refractive Error (dioptres) +0.51$)$. It increased significantly with decreasing uncorrected visual acuity $(r=-0.11 ; P<0.001 ; 95 \% \mathrm{CI}:-0.30,-0.17)$ and decreasing best-corrected visual acuity $(r=-0.056$; $P<0.001 ; 95 \% \mathrm{CI}:-0.31 ;-0.09)$. It did not vary 


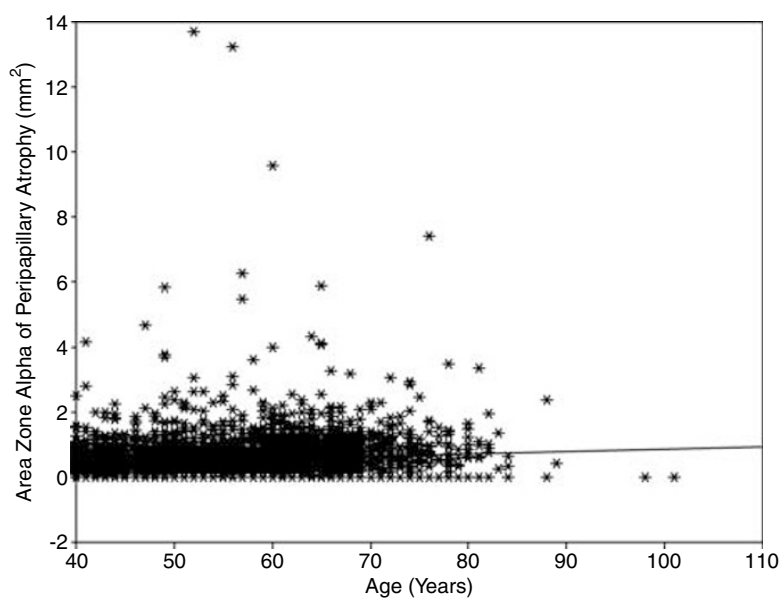

Figure 1 Scattergram showing the correlation between area of alpha zone of peripapillary atrophy and age in the Beijing Eye Study.

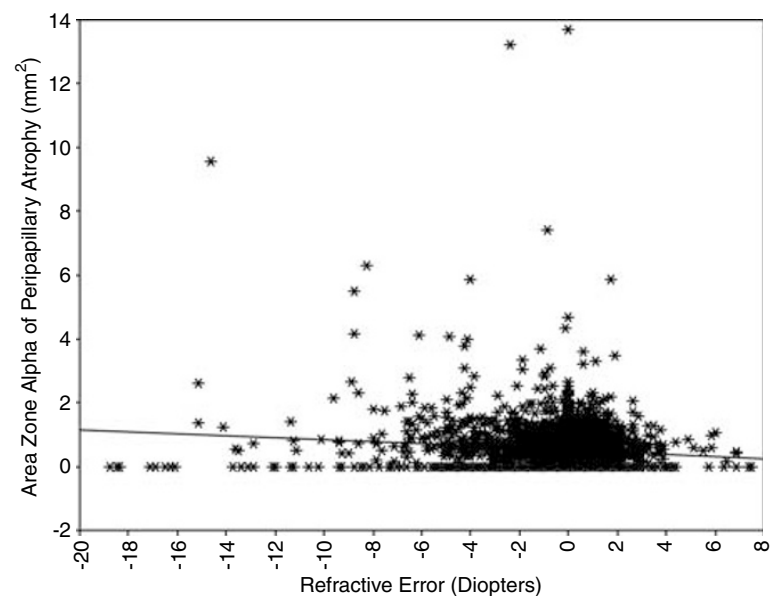

Figure 2 Scattergram showing the correlation between area of alpha zone of peripapillary atrophy and refractive error in the Beijing Eye Study.

significantly $(P=0.10 ; 95 \% \mathrm{CI}:-0.001,0.07)$ between male $\left(0.54 \pm 0.64 \mathrm{~mm}^{2}\right)$ and female subjects $\left(0.51 \pm 0.64 \mathrm{~mm}^{2}\right)$. It was not associated with family income $(P=0.086 ; r=0.028)$.

In multivariate analysis, with area of alpha zone as dependent variable, and age, refractive error, optic disc area, uncorrected visual acuity, and best-corrected visual acuity as independent variables, zone of alpha zone was still significantly correlated with increasing age $(P<0.001 ; 95 \%$ CI: 0.005, 0.010), myopic refractive error $(P<0.001 ; 95 \% \mathrm{CI}:-0.034,-0.012)$, optic disc area $(P<0.001 ; 95 \% \mathrm{CI}: 0.051,0.127)$, and uncorrected visual acuity ( $P=0.006$; 95\% CI: $-0.204,-0.035)$. Best-corrected visual acuity was marginally significantly associated with area of alpha zone $(P=0.09 ; 95 \% \mathrm{CI}:-0.019,0.270)$.

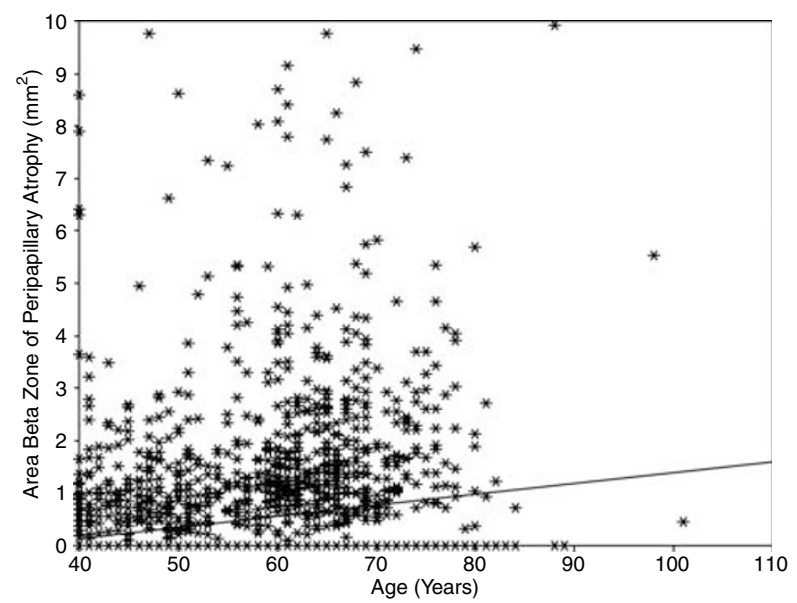

Figure 3 Scattergram showing the correlation between area of beta zone of peripapillary atrophy and age in the Beijing Eye Study.

Area of beta zone measured $0.46 \pm 1.82 \mathrm{~mm}^{2}$ (median, $0.0 \mathrm{~mm}^{2}$; range $0.00-32.85 \mathrm{~mm}^{2}$ ). It was significantly widest in the temporal peripapillary region, followed by the temporal inferior region, the temporal superior region, and finally the nasal region. It was found in 802 $(19.9 \%)$ eyes. Its frequency was significantly $(P<0.001)$ higher in the temporal peripapillary region $(793 / 4027$ or $19.7 \%$ ) than in the temporal inferior region $656 / 4027$ or $16.3 \%)$, in which it was detected more often $(P<0.001)$ than in the temporal superior region $(610 / 4027$ or $15.1 \%)$, in which it occurred more frequently $(P<0.001)$ than in the nasal region $224 / 4027$ or $5.6 \%$ ).

Beta zone area was significantly correlated with optic disc size (correlation coefficient $r=0.36$; $P<0.001$; 955CI: $1.04 ; 1.23)$. It increased with age $(r=0.11 ; P<0.001 ; 95 \%$ CI: 0.015, 0.26) (Figure 3; Equation of the regression line: Area Beta Zone $\left(\mathrm{mm}^{2}\right): 0.021 \times$ Age (years) -0.68$)$ and myopic refractive error $(r=-0.57 ; P<0001 ; 95 \% \mathrm{CI}$ : $-0.51 ;-0.46)$ (Figure 4 ). It did not vary significantly $(P=0.78 ; 95 \%$ CI: $-0.13 ; 0.09)$ between male $\left(0.45 \pm 1.41 \mathrm{~mm}^{2} ; 95 \% \mathrm{CI}: 0.38,0.51\right)$ and female subjects $\left(0.46 \pm 2.08 \mathrm{~mm}^{2} ; 95 \% \mathrm{CI}: 0.38,0.55\right)$. It was significantly correlated with low uncorrected visual acuity $(r=-0.28$; $P<0.001 ; 95 \%$ CI: $-1.85,-1.50)$ and low best-corrected visual acuity $(r=-0.31 ; P<0.001 ; 95 \% \mathrm{CI}:-3.52,2.92)$.

In multivariate analysis, with area of beta zone as dependent variable, and age, refractive error, optic disc area, uncorrected visual acuity, and best-corrected visual acuity as independent variables, zone of beta zone was still significantly correlated with increasing age $(P<0.001 ; 95 \%$ CI: $0.018,0.028)$, myopic refractive error $(P<0.001 ; 95 \% \mathrm{CI}:-0.47,-0.42)$, optic disc area $(P<0.001 ; 95 \%$ CI: $0.36,0.52)$, uncorrected visual acuity $(P=0.005 ; 95 \% \mathrm{CI}: 0.27,0.64)$, and best-corrected visual acuity $(P<0.001 ; 95 \% \mathrm{CI}:-2.43,-1.80)$. 


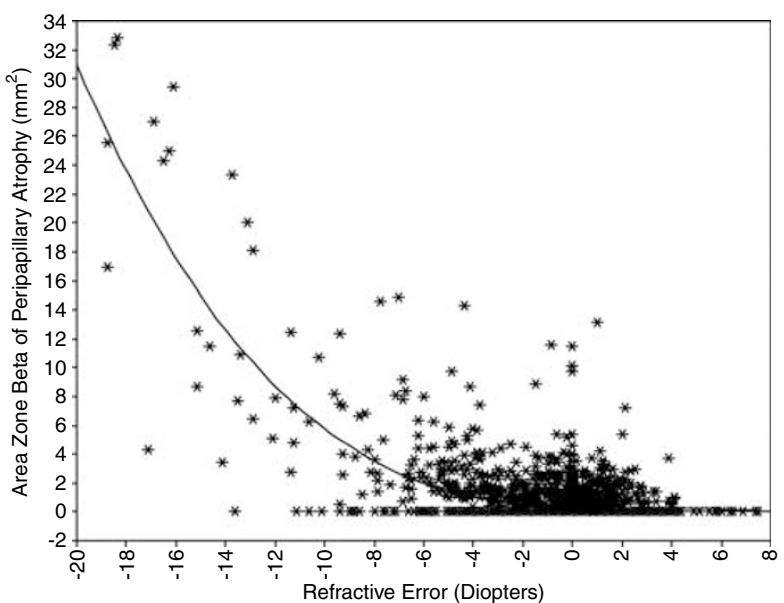

Figure 4 Scattergram showing the correlation between area of beta zone of peripapillary atrophy and refractive error in the Beijing Eye Study.

To exclude the influence of high myopia defined as a myopic refractive error of more than $-8 \mathrm{~d}$, a separate statistical analysis was performed excluding highly myopic eyes. In a multivariate analysis, with area of beta zone as dependent variable, and age, refractive error, optic disc area, uncorrected visual acuity, and bestcorrected visual acuity as independent variables, zone of beta zone was again significantly correlated with increasing age $(P<0.001 ; 95 \% \mathrm{CI}: 0.015,0.022)$, myopic refractive error $(P<0.001 ; 95 \% \mathrm{CI}:-0.21,-0.17)$, optic disc area $(P<0.001 ; 95 \% \mathrm{CI}: 0.19,0.30)$, uncorrected visual acuity $(P=0.004 ; 95 \% \mathrm{CI}:-0.32,0.06)$, and bestcorrected visual acuity $(P<0.001 ; 95 \% \mathrm{CI}:-0.71,-0.25)$.

\section{Discussion}

Peripapillary chorioretinal atrophy has been described by Elschnig, Bücklers, and others around the beginning of the 20th century who called it 'halo glaucomatosus' if it encircled the optic disc. ${ }^{9-11}$ Later, Primrose, Hayreh, Wilensky and Kolker, Anderson, Airaksinen, and other investigators confirmed the observations describing the occurrence of peripapillary atrophy in eyes with glaucoma. ${ }^{2,3,12-29}$ Heijl and Samander ${ }^{17}$ found a spatial correlation between the peripapillary chorioretinal atrophy and the location of the most marked visual field loss. Anderson ${ }^{13}$ described that the presence or extent of a crescent correlated with the glaucomatous disc damage. In indirect and direct clinical-histological comparisons, beta zone correlates with a complete loss of retinal pigment epithelium cells and a markedly diminished count of retinal photoreceptors. ${ }^{19,25,30,31}$ Correspondingly, beta zone corresponds psychophysically to an absolute scotoma, and alpha zone to a relative scotoma. ${ }^{32}$
In previous studies on Caucasian subjects, both alpha zone and beta zone were largest and were most frequently located in the temporal horizontal sector, followed by the inferior temporal area and the superior temporal region. ${ }^{4-6}$ They were smallest and most rarely found in the nasal peripapillary area. Alpha zone was present in almost all normal eyes and was thus more common than beta zone. The frequency of the latter was about $15-20 \% .^{4-6,21}$

The present population-based study on elderly Chinese in Northern China agrees with the previous hospital-based studies as well as the Rotterdam study on normal eyes of Caucasians. In the Chinese, alpha zone was present in the vast majority of subjects included in the study and was significantly more frequent than beta zone, which occurred in about $20 \%$ of the eyes. Both zones were widest in the temporal peripapillary disc region, followed by the temporal inferior region, the temporal superior region, and finally the nasal region. They were associated with age. The increase with age was, however, not marked, with an enlargement of about $0.21 \mathrm{~mm}^{2}$ per decade of age (Figure 3 ). As in the preceding studies, both zones did not vary significantly between female and male subjects.

What is new in the present study is, that alpha zone and beta zone of peripapillary atrophy were significantly associated with uncorrected visual acuity and with bestcorrected visual acuity. The result found in univariate analysis may have been explainable by the association between visual acuity and refractive error. The correlation between peripapillary atrophy and visual acuity, was, however, confirmed in a multivariate statistical analysis. It indicates that the relationship between myopic refractive error and peripapillary atrophy is not sufficient to explain the association between beta zone of peripapillary atrophy and low visual acuity. Future studies may show whether the association between peripapillary atrophy and visual acuity is due to factors such as increased corneal astigmatism with amblyopia, macular changes in the vicinity of the peripapillary region ${ }^{33}$ or other factors. These other factors may include glaucoma, as previous hospital-based investigations have shown a relationship between beta zone of the peripapillary atrophy and glaucoma. $^{2-5,13-24,26-28,30,34-42}$

As beta zone of peripapillary is associated with glaucomatous optic neuropathy and has been reported to be a predictive factor for further progression of chronic open-angle glaucoma, ${ }^{2-5,13-24,26-28,30,34-42}$ and because different types of the chronic open-angle glaucomas differ in the amount of beta zone of peripapillary atrophy, ${ }^{1,43-45}$ the data of the present population-based study in Chinese may serve for glaucoma diagnosis of Chinese patients. They may additionally be helpful for 
the differentiation between glaucomatous optic nerve damage and nonglaucomatous optic nerve atrophy, as in the latter, peripapillary atrophy usually does not enlarge. ${ }^{46-48}$ Interestingly, frequency of alpha and beta zone of peripapillary atrophy did not vary between the elderly Chinese examined in the present study and South Indian examined in a previous population-based investigation. ${ }^{49}$

There are limitations of the present study. A major concern in any prevalence study is nonparticipation. The Beijing Eye Study had a reasonable response rate of $83.4 \%$, however, differences between participants and nonparticipants can lead to a selection artefact and may have influenced the results. Another limiting factor of the present study is that subjects for whom a dense cataract prevented to take fundus photographs might additionally have had marked peripapillary atrophy. It may have artificially reduced the measurement figures for peripapillary atrophy in the present study.

In conclusion, alpha zone and beta zone of peripapillary atrophy show a similar frequency in elderly Chinese as in Caucasians and South Indians. In all these population, alpha zone is present in about the majority of subjects, whereas beta zone occurs in about $20 \%$ of the subjects. In all three groups, both zones are significantly the widest and are found significantly $(P<0.001)$ most often in the temporal peripapillary region, followed by the temporal inferior region, the temporal superior region, and finally the nasal region. Optic disc size, age, and myopic refractive error positively influence the size of alpha zone and beta zone of peripapillary atrophy. Interestingly, beta zone was associated with low uncorrected visual acuity and low best-corrected visual acuity in the present study, a finding that needs further evaluation.

\section{References}

1 Jonas JB, Budde WM, Panda-Jonas S. Ophthalmoscopic evaluation of the optic nerve head. Surv Ophthalmol 1999; 43: 293-320.

2 Primrose J. The incidence of the peripapillary halo glaucomatosus. Trans Ophthalmol Soc UK 1971; 89: 585-588.

3 Wilensky JT, Kolker AE. Peripapillary changes in glaucoma. Am J Ophthalmol 1976; 81: 341-345.

4 Jonas JB, Nguyen NX, Gusek GC, Naumann GOH. Peripapillary chorio-retinal atrophy in normal and glaucoma eyes. I. Morphometric data. Invest Ophthalmol Vis Sci 1989; 30: 908-918.

5 Jonas JB, Fernández MC, Naumann GOH. Glaucomatous peripapillary atrophy: occurrence and correlations. Arch Ophthalmol 1992; 110: 214-222.

6 Ramrattan RS, Wolfs RCW, Hofmann A, Jonas JB, de Jong PTVM. Determinants of optic disk characteristics in a general population. The Rotterdam Study. Ophthalmology 1999; 106: 1588-1596.
7 Xu L, Li J, Cui T, Hu A, Zheng Y, Li Y et al. Visual acuity in Northern China in an urban and rural population. The Beijing Eye Study. Br J Ophthalmol 2005; 89: 1089-1093.

8 Littmann H. Zur Bestimmung der wahren Größe eines Objektes auf dem Hintergrund des lebenden Auges. Klin Monatsbl Augenheilkd 1982; 180: 286-289.

9 Elschnig A. Das Colobom am Sehnerveneintritte und der Conus nach unten. Archiv für Ophthalmologie 1900; 51: 391-430.

10 Elschnig A. Der normale Sehnerveneintrittt des menschlichen Auges. Denkschrift der kais Akad der Wiss, Wien, Math-naturw Kl 1901; 70: 219-310.

11 Bücklers M. Anatomische Untersuchung über die Beziehung zwischen der senilen und myopischen circumpapillären Aderhautatrophie. Unter Beifügen eines Falles von hochgradiger Anisometropie. Arch für Ophthalmol 1929; 121: 243-283.

12 Hayreh SS. Blood supply of the optic nerve head and its role in optic atrophy, glaucoma and oedema of the optic disc. $\mathrm{Br}$ J Ophthalmol 1969; 53: 721-748.

13 Anderson DR. Correlation of the peripapillary damage with the disc anatomy and field abnormalities in glaucoma. Doc Ophthalmol Proc Sers 1983; 35: 1-10.

14 Airaksinen PJ, Juvala PA, Tuulonen A, Alanko AI, Valkonen $\mathrm{R}$, Tuohino A. Change of peripapillary atrophy in glaucoma. In: Krieglstein GK (ed). Glaucoma Update III. Heidelberg: Springer-Verlag, 1987, pp 97-102.

15 Buus DR, Anderson DR. Peripapillary crescents and halos in normal-tension glaucoma and ocular hypertension. Ophthalmology 1989; 96: 16-19.

16 Greve EL, Geijson HC. The relationship between excavation and visual field in glaucoma patients with high and low intraocular pressures. In: Greve EL, Heijl A (eds). 5th International Visual Field Symposium. Junk Publishers: The Hague, 1983, pp 35-42.

17 Heijl A, Samander C. Peripapillary atrophy and glaucomatous visual field defects. Doc Ophthalmol Proc Ser 1985; 42: 403-407.

18 Nevarez J, Rockwood EJ, Anderson DR. The configuration of peripapillary tissue in unilateral glaucoma. Arch Ophthalmol 1988; 106: 901-903.

19 Fantes FE, Anderson DR. Clinical histologic correlation of human peripapillary anatomy. Ophthalmology 1989; 96: 20-25.

20 Rockwood EJ, Anderson DR. Acquired peripapillary changes and progression in glaucoma. Graefe's Arch Clin Exp Ophthalmol 1988; 226: 510-515.

21 Jonas JB, Naumann GOH. Peripapillary chorio-retinal atrophy in normal and glaucoma eyes. II. Correlations. Invest Ophthalmol Vis Sci 1989; 30: 919-926.

22 Geijssen C. Studies on normal pressure glaucoma. Kugler Publications: Amstelveen Netherlands, 1991, pp 1-238.

23 Derick RJ, Pasquale LR, Pease ME, Quigley HA. A clinical study of peripapillary crescents of the optic disc in chronic experimental glaucoma in monkey eyes. Arch Ophthalmolm 1994; 112: 846-850.

24 Puska P, Raitta C. Peripapillary atrophy in unilateral capsular glaucoma. Graefe's Arch Clin Exp Ophthalmol 1993; 231: 642-646.

25 Kubota T, Jonas JB, Naumann GOH. Direct clinicohistological correlation of peripapillary chorioretinal atrophy. Br J Ophthalmol 1993; 77: 103-106.

26 Quigley HA, Pease ME. Change in the optic disc and nerve fibre layer estimated with the glaucoma-scope in monkey eyes. J Glaucoma 1996; 5: 106-116. 
27 Park KH, Tomita G, Liou SY, Kitazawa Y. Correlation between peripapillary atrophy and optic nerve damage in normal-tension glaucoma. Ophthalmology 1996; 103: 1899-1906.

28 Meyer JH, Guhlmann M, Funk J. Blind spot size depends on the optic disc topography: a study using SLO controlled scotometry and the Heidelberg retina tomograph. $\mathrm{Br} \mathrm{J}$ Ophthalmol 1997; 81: 355-359.

29 Hayreh SS, Jonas JB, Zimmerman MB. Peripapillary chorioretinal atrophy in chronic high-pressure experimental glaucoma in rhesus monkeys. Invest Ophthalmol Vis Sci 1998; 39: 2296-2303.

30 Jonas JB, Königsreuther KA, Naumann GOH. Optic disc histomorphometry in normal eyes and eyes with secondary angle-closure glaucoma. II. Peripapillary region. Graefe's Arch Clin Exp Ophthalmol 1992; 230: 134-139.

31 Curcio CA, Saunders PL, Younger PW, Malek G. Peripapillary chorioretinal atrophy: Bruch's membrane changes and photoreceptor loss. Ophthalmology 2000; 107: 334-343.

32 Jonas JB, Gusek GC, Fernández MC. Correlation of the blind spot size to the area of the optic disc and peripapillary atrophy. Am J Ophthalmol 1991; 111: 559-565.

33 Budde WM, Jonas JB, Schönherr U. Age-related maculopathy and optic disc morphology. Brief report. Am J Ophthalmol 1999; 127: 220-221.

34 Araie M, Sekine M, Suzuki Y, Koseki N. Factors contributing to the progression of visual field damage in eyes with normal-tension glaucoma. Ophthalmology 1990; 101: 1440-1444.

35 Tezel G, Kass MA, Kolker AE, Wax MB. Comparative optic disc analysis in normal pressure glaucoma, primary openangle glaucoma, and ocular hypertension. Ophthalmology 1996; 103: 2105-2113.

36 Tuulonen A, Jonas JB, Välimäki S, Alanko HI, Airaksinen PJ. Interobserver variation in the measurements of peripapillary atrophy in glaucoma. Ophthalmology 1996; 103 535-541.

37 Sugiyama K, Tomita G, Kitazawa Y, Onda E, Shinohara H, Park KH. The associations of optic disc hemorrhage with retinal nerve fibre layer defect and peripapillary atrophy in normal-tension glaucoma. Ophthalmology 1997; 104: 1926-1933.
38 Tezel G, Kolker AE, Kass MA, Wax MB, Gordon M, Sigmund KD. Parapapillary chorioretinal atrophy in patients with ocular hypertension. I. An evaluation as a predictive factor for the development of glaucomatous damage. Arch Ophthalmol 1997; 115: 1503-1508.

39 Tezel G, Kolker AE, Wax MB, Kass MA, Gordon M, Sigmund KD. Parapapillary chorioretinal atrophy in patients with ocular hypertension. II. An evaluation of progressive changes. Arch Ophthalmol 1997; 115: 1509-1514.

40 Uchida H, Ugurlu S, Caprioli J. Increasing peripapillary atrophy is associated with progressive glaucoma. Ophthalmology 1998; 105: 1541-1545.

41 Jonas JB, Martus P, Budde WM, Jünemann A, Hayler JK. Small neuroretinal rim and large peripapillary atrophy as predictive factors for progression of glaucomatous optic neuropathy. Ophthalmology 2002; 109: 1561-1567.

42 Jonas JB, Martus P, Budde WM, Hayler JK. Morphologic predictive factors for the development of optic disc hemorrhages in glaucoma. Invest Ophthalmol Vis Sci 2002; 43: 2956-2961.

43 Jonas JB, Gründler AE. Optic disc morphology in 'agerelated atrophic glaucoma'. Graefe's Arch Clin Exp Ophthalmol 1996; 234: 744-749.

44 Jonas JB, Dichtl A. Optic disc morphology in myopic primary open-angle glaucoma. Graefe's Arch Clin Exp Ophthalmol 1997; 235: 627-633.

45 Jonas JB, Gründler AE. Optic disc morphology in juvenile primary open-angle glaucoma. Graefe's Arch Clin Exp Ophthalmol 1996; 234: 750-754.

46 Jonas JB, Fernández MC, Naumann GOH. Peripapillary atrophy and retinal vessel caliber in nonglaucomatous optic nerve damage. Invest Ophthalmol Vis Sci 1991; 32: 2942-2947.

47 Jonas JB, Xu L. Optic disc morphology in eyes after nonarteritic anterior ischemic optic neuropathy. Invest Ophthalmol Vis Sci 1993; 34: 2260-2265.

48 Hayreh SS, Jonas JB. Optic disc morphology after arteritic anterior ischemic optic neuropathy. Ophthalmology 2001; 108: 1586-1594.

49 Jonas JB, Thomas R, George R, Berenshtein E, Muliyil J. Optic disc morphology in South India: the Vellore Eye Study. Br J Ophthalmol 2003; 87: 189-196. 